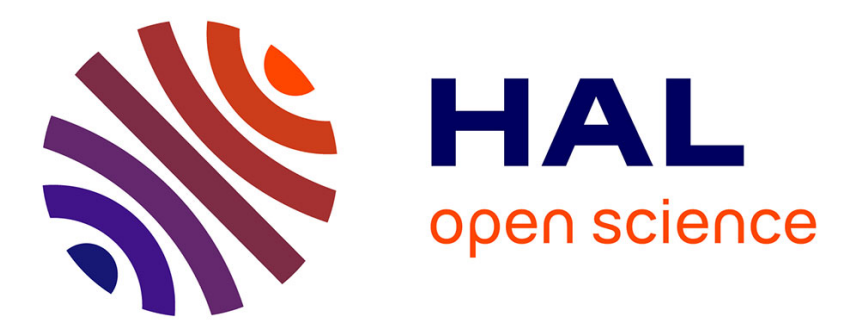

\title{
MÖSSBAUER STUDIES OF THE ACTIVATION OF AMMONIA SYNTHESIS CATALYSTS
}

\author{
B. Clausen, S. Mørup, H. Topsøe, R. Candia, E. Jensen, A. Baranski, A.
} Pattek

\section{> To cite this version:}

B. Clausen, S. Mørup, H. Topsøe, R. Candia, E. Jensen, et al.. MÖSSBAUER STUDIES OF THE ACTIVATION OF AMMONIA SYNTHESIS CATALYSTS. Journal de Physique Colloques, 1976, 37 (C6), pp.C6-245-C6-248. 10.1051/jphyscol:1976649 . jpa-00216759

\section{HAL Id: jpa-00216759 https://hal.science/jpa-00216759}

Submitted on 1 Jan 1976

HAL is a multi-disciplinary open access archive for the deposit and dissemination of scientific research documents, whether they are published or not. The documents may come from teaching and research institutions in France or abroad, or from public or private research centers.
L'archive ouverte pluridisciplinaire HAL, est destinée au dépôt et à la diffusion de documents scientifiques de niveau recherche, publiés ou non, émanant des établissements d'enseignement et de recherche français ou étrangers, des laboratoires publics ou privés. 


\title{
MÖSSBAUER STUDIES OF THE ACTIVATION OF AMMONIA SYNTHESIS CATALYSTS
}

\author{
B. S. CLAUSEN, S. MØRUP \\ Laboratory of Applied Physics II, Technical University of Denmark \\ DK-2800 Lyngby, Denmark \\ H. TOPSøE, R. CANDIA, E. J. JENSEN \\ Haldor Topsøe Research Laboratories, DK-2800 Lyngby, Denmark \\ A. BARANSKI and A. PATTEK \\ Institute of Chemistry, Jagiellonian University, 30-060 Crakow, Poland
}

\begin{abstract}
Résumé. - L'article présente des études Mössbauer de l'activation (réduction) de catalyseurs de commerce, basés sur magnétite et fréquemment promotés, pour la synthèse de l'ammoniac. Les études s'effectuaient sur deux catalyseurs contenant des quantités différentes (4\% et $27 \%$ de wüstite. Le procédé de réduction fut suivi de spectroscopie Mössbauer in situ permettant une étude des cinétiques de réduction. On a trouvé que la phase wüstite est réduite plus vite que la magnétite. Seulement le catalyseur qui retient la quantité moindre de wüstite se trouvait réduit selon le modèle noyau-et-coquille. Une comparaison avec des observations microscopiques élucide les désaccords susmentionnés. En contraste avec l'étude préalable de catalyseurs singulièrement promotés, on a trouvé sous conditions opératoires la présence de fer non réduit.
\end{abstract}

\begin{abstract}
Mössbauer studies of the activation (reduction) of commercial magnetite based multiple promoted ammonia synthesis catalysts are reported. These studies were carried out for two catalysts containing different amounts ( $4 \%$ and $27 \%$ ) of wïstite. The reduction process was followed by in situ Mössbauer spectroscopy which allowed the reduction kinetics to be investigated. The wiistite phase was found to reduce much faster than the magnetite. Only the catalyst containing the small amount of wüstite was found to reduce according to the core and shell model. Comparison with microscopic observations elucidates the above discrepancies. In contrast to previous studies on singly promoted catalysts non-reduced iron was found present under working conditions.
\end{abstract}

1. Introduction. - Ammonia synthesis is industrially carried out by passing at high temperature and pressure a mixture of $\mathrm{N}_{2}$ and $\mathrm{H}_{2}$ over a catalyst which in its active state consists of metallic iron particles ( $200 \AA$ ) with small amounts of promoters such as $\mathrm{Al}_{2} \mathrm{O}_{3}, \mathrm{CaO}, \mathrm{K}_{2} \mathrm{O}$, and $\mathrm{MgO}$ [1]. $\mathrm{K}_{2} \mathrm{O}$ is added in order to increase the activity of the catalyst, whereas $\mathrm{Al}_{2} \mathrm{O}_{3}$ is added to minimize sintering of the iron particles. The active state of the catalyst is obtained by hydrogen reduction of a magnetite precursor structure often containing small amounts of wüstite. The composition of the unreduced catalyst (e. g. the amount of wüstite) as well as the way in which it is reduced is most important for obtaining a catalyst with high activity $[1,2]$. During the reduction of the essentially non-porous oxide, small particles of metallic iron are formed leading to a highly porous structure of the completely reduced catalyst. Baranski et al. [3] found that the reduction of an industrial catalyst (TOPSØE KMI) was in accordance with the core and shell model described by for example Seth and Ross [4]. According to this model a partly reduced oxide particle (originally assumed to be a sphere) consists of an unreduced core surrounded by a porous shell of iron. The rate of reduction is then determined by the area of the metal-oxide interface and the diffusion of gaseous reactants and products through the porous shell.

In situ Mössbauer spectroscopy is an ideal technique for the study of the reduction of ammonia synthesis catalysts since it is possible to measure simultaneously the kinetics of the reduction of the wüstite and magnetite phases.

In the present paper we report studies of the structure of the unreduced as well as the reduced catalyst and the influence of wüstite on the reduction process.

2. Experimental. - The samples investigated were of the same type as the commercial TOPSØE KMI catalyst containing about $3 \mathrm{Wt} \%$ of $\mathrm{Al}_{2} \mathrm{O}_{3}$ and $\mathrm{CaO}$ and smaller amounts of $\mathrm{K}_{2} \mathrm{O}, \mathrm{MgO}$, and $\mathrm{SiO}_{2}$. The two samples (I and II) used in the Mössbauer experiments contained 4 and $27 \mathrm{Wt} \%$ wüstite (calculated as $\mathrm{Fe}_{0.91} \mathrm{O}$ as will be discussed later). The samples 
having particle sizes between 0.01 and $0.07 \mathrm{~mm}$ were placed in a variable temperature cell, which allowed hydrogen to pass over the catalysts while the spectra were obtained. The spectra used for the kinetic studies were recorded after fast cooling to room temperature in order to avoid reduction during the data collection.

The Mössbauer spectra were obtained using conventional constant acceleration Mössbauer spectrometers with sources of ${ }^{57} \mathrm{Co}$ in $\mathrm{Pd}$ and $\mathrm{Rh}$.

3. Results and discussion. - The figures $1 a$ and $1 b$ show the Mössbauer spectra of the unreduced catalysts with the small and large amounts of wüstite, respectively. Figure $1 c$ shows the spectrum of pure $\mathrm{Fe}_{3} \mathrm{O}_{4}$.

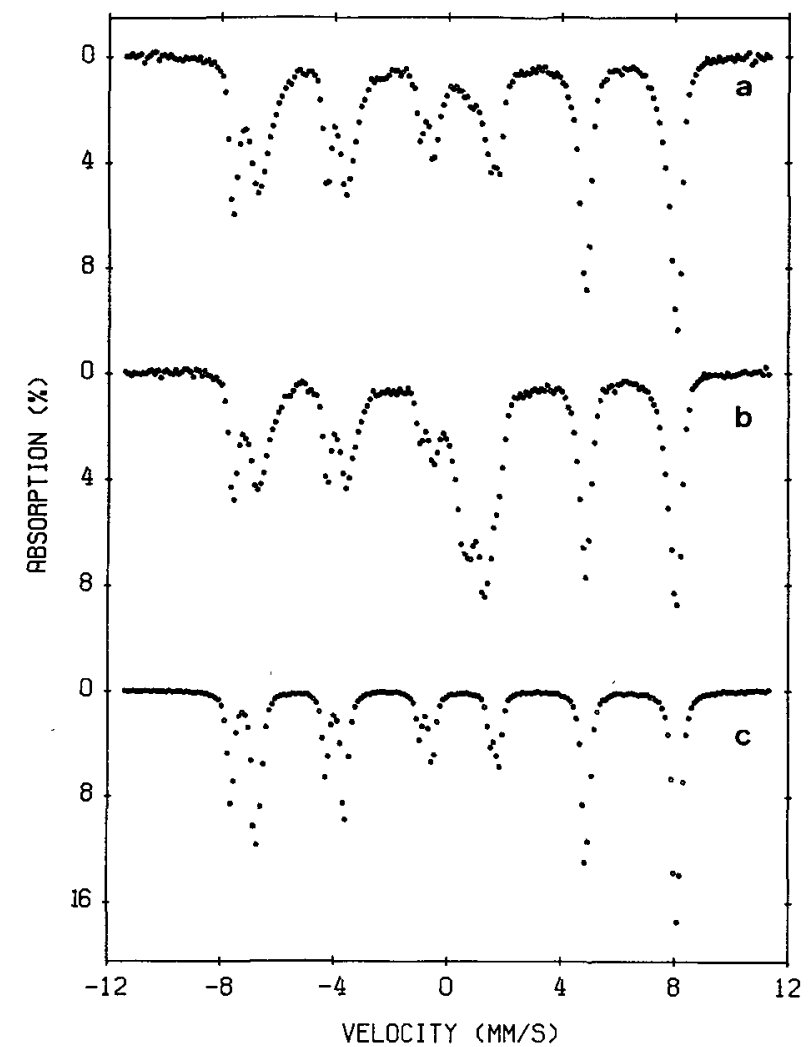

FIG. 1. - Mössbauer spectra of the unreduced samples : a) Sample I with $4 \mathrm{wt} \%$ wüstite ; b) Sample II with $27 \mathrm{wt} \%$ wüstite ; c) Pure $\mathrm{Fe}_{3} \mathrm{O}_{4}$.

An asymmetrical broadening of the lines corresponding to the octahedral sites (the B-sites) in the spinel structure of the catalyst is observed. The wüstite content of the two samples can be calculated from the computer fitted areas using a relative f-factor which was obtained experimentally from a mixture of wüstite and magnetite of known composition. It should be emphasized that from chemical analysis of the $\mathrm{Fe}^{2+}$ and $\mathrm{Fe}^{3+}$ content in the samples, the amount of wüstite and magnetite cannot be determined directly since the stoichiometries and compositions of these phases are not a priori known. Mössbauer spectroscopy does allow the determination of the relative amount of iron atoms in the two phases. From an analysis of the wüstite component its stoichiometry can also be estimated [5]. The amount of wüstite and its stoichiometry $\left(\sim \mathrm{Fe}_{0.91} \mathrm{O}\right)$ determined in this way is consistent with chemical analysis. Information about the influence of the promoters on the magnetite phase is

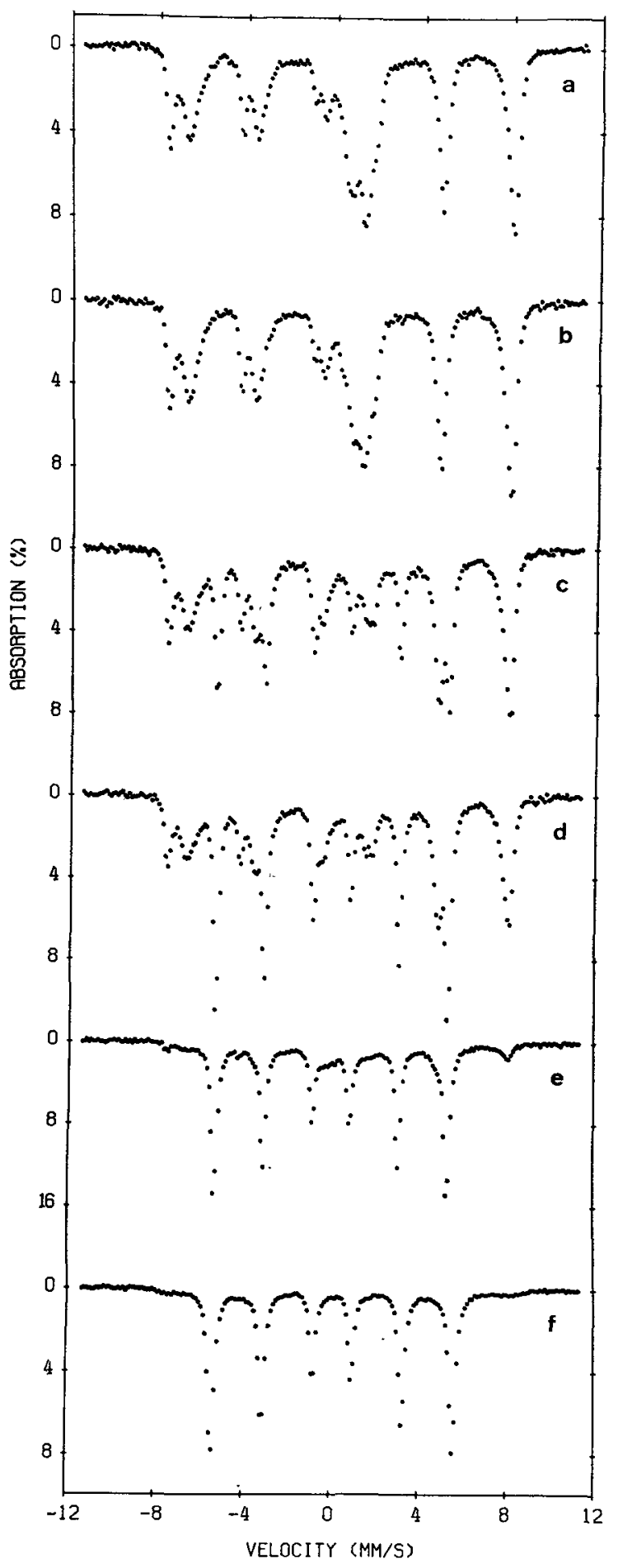

FIG. 2. - Mössbauer spectra of Sample II obtained after fast cooling to room temperature at different times of reduction at $675 \mathrm{~K}: a) 0$ hours ; b) 0.2 hours ; c) 1 hour ; d) 4 hours; e) 8 hours; $f$ ) shows the spectrum obtained at $78 \mathrm{~K}$ after reduction for several days at $825 \mathrm{~K}$. 
also available from Mössbauer spectroscopy. Although the magnetite spectral components are nearly identical in Samples I and II, they differ substancially from that of pure magnetite (Figure 1c). This clearly shows that some of the promoters have entered the spinel lattice. The hyperfine fields for the $\mathrm{A}$ and especially the $\mathbf{B}$ lines are slightly reduced, and the $\mathrm{B}$ lines have become asymmetrically broadened.

The octahedral (B) sites in pure $\mathrm{Fe}_{3} \mathrm{O}_{4}$ contain equal amounts of $\mathrm{Fe}^{3+}$ and $\mathrm{Fe}^{2+}$. These sites give only rise to a single sixline spectrum at room temperature because of the fast « electron hopping » between $\mathrm{Fe}^{3+}$ and $\mathrm{Fe}^{2+}$ ions. The asymmetrically broadening of the $\mathrm{B}$ lines in the spectra of the catalysts must be due to the fact that aluminium and calcium to some extent enter the magnetite structure as also seen by microprobe analyses [6]. Broad B lines have been observed by Hrýnkiewicz et al. [7] for $\mathrm{Ca}$ substituted magnetites and by Dehe and Seidel [8] for Al substituted magnetites.

Figure 2 shows Mössbauer spectra of the catalyst with the large amount of wüstite obtained after different times of reduction at $675 \mathrm{~K}$. By comparison of the wüstite components of the spectra in Figures $2 a$ and $2 b$ with spectra of wüstites of known stoichiometries [5] it is observed that the wüstite phase being non-stoichiometric in the unreduced sample is transformed into a more stoichiometric compound before reduction to metallic iron. The sequence of spectra showing the reduction of the catalyst did not reveal other phases
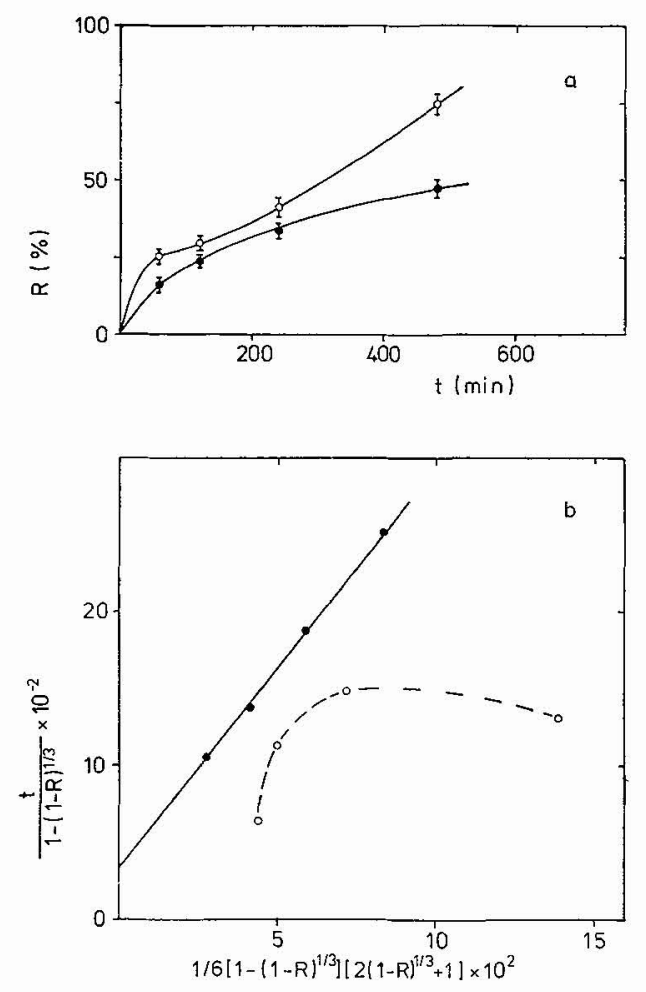

FIG. 3. - Kinetic data obtained for the reduction of Sample I (closed circles) and Sample II (open circles) : a) the reduction degree $\mathrm{R}$ as a function of the reduction time $t ; b) \mathrm{R}$ and $t$ plotted in the linearized coordinate system (see text). than magnetite and wïstite (of various stoichiometries) or magnetite and $\alpha-\mathrm{Fe}$. Thus, the magnetite phase reduces directly to pure $\alpha$-Fe.

Figure $3 a$ shows the reduction degree, $R$, obtained from Mössbauer spectroscopy, as a function of the reaction time $t$ for Samples I and II. R is defined as the amount of metallic iron formed at time $t$ divided by the total amount of iron atoms in the sample. The above data are plotted in Figure $3 b$ in a linearized form using the equation describing the core and shell reduction [4]. A reduction that follows this model will exhibit a straight line in this coordinate system. From the figure it is seen that only the reduction of the catalyst with the small amount of wüstite can be described by the core and shell model.

From the Mössbauer spectra we observe that the wuistite is reduced much faster than the magnetite. The wüstite is completely reduced at a time when hardly any reduction of the magnetite has taken place. Microprobe studies of Sample II [6] show that in the unreduced catalyst the wüstite is present as grains distributed throughout the magnetite structure. The Mössbauer results of Sample II indicate that the reduction of these grains at an early stage results in a reduction

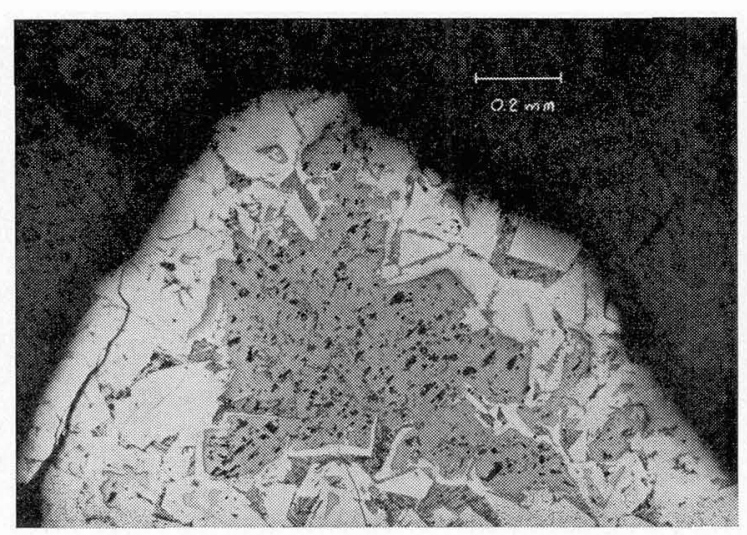

(a)

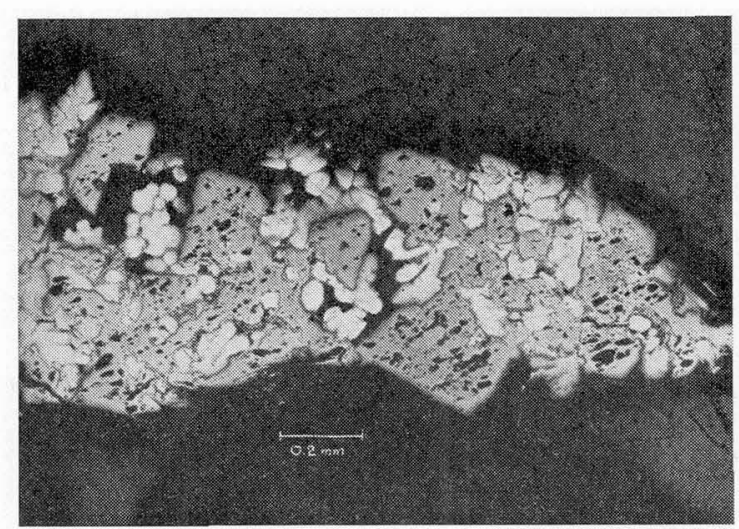

(b)

FIG. 4. - Optical micrographs of partly reduced particles of Samples I and II. Light areas represent material which has been reduced to metallic iron. The gray areas correspond to the unreduced magnetite phase : a) Sample I reduced $75 \%$ at $775 \mathrm{~K} ; b$ ) Sample II reduced $40 \%$ at $775 \mathrm{~K}$. 
kinetics of the magnetite which does not follow the core and shell model. This is presumably due to the formation of many new places, where the reduction of the magnetite can take place. The micrograph of a partly reduced grain of Sample II (Fig. 4b) shows in fact a structure deviating from the core and shell structure. The structure of a partly reduced grain of Sample I (Fig. 4a) shows as expected evidence of a core and shell structure.

A small amount of non-reduced iron is present in the catalyst even after severe reduction. Figure $2 f$ shows the spectrum obtained at $78 \mathrm{~K}$ of the catalyst after reduction for several days at $825 \mathrm{~K}$. Apart from the spectral component of pure $\alpha$-Fe a magnetically split component of small intensity is observed with a hyperfine field of about $500 \mathrm{kOe}$. This component is paramagnetic at the reduction temperature. This finding is in contrast to an earlier study [9] where a catalyst containing only $\mathrm{Al}_{2} \mathrm{O}_{3}$ as promoter in its reduced state showed only metallic iron to be present. Thus the present study suggests that in a multiple promoted ammonia synthesis catalyst $\mathrm{Ca}$ together with iron (and possibly $\mathrm{Al}$ ) form a difficult reducible phase stable at the ammonia synthesis conditions.

\section{References}

[1] Nielsen, A., An Investigation on Promoted Iron Catalysts for the Synthesis of Ammonia, 3rd ed., (Jul. Gjellerups Forlag, Copenhagen) 1968.

[2] Kuznecov, L. D., Chem. Techn. 15 (1963) 211.

[3] Baranski, A., Bielanski, A. and Pattek, A., J. Catal. 26 (1972) 286

[4] SeTH, B. B. L. and Ross, H. U., Trans AIME 233 (1965) 180.

[5] Checherskaya, L. F., Romanov, V. P. and Tatsienko, P. A., Phys. Stat. Sol (a) 19 (1973) K 177.
[6] Jensen, E. J., Topsøe, H., Sørensen, O., Krag, F., CanDia, R., Clausen, B. S. and Mørup, S., Scand. J. Metallurgy (to be published).

[7] Hrynkiewicz, A. Z., Kulgawczuk, D. S., Mazanex, E. S., Pustówka, A. J., SAwicki, J. A. and Wyderko, M. E., Phys. Stat. Sol (b) 43 (1971) 401.

[8] Dehe, G. and Seidel, B., Phys. Stat. Sol (a) 29 (1975) K 47.

[9] Topsøe, H., Dumesic, J. A. and Boudart, M., J. Catal. 28 (1973) 477. 